\title{
3. MORPHOTECTONICS OF THE LAU BASIN SEAFLOOR-IMPLICATIONS FOR THE OPENING HISTORY OF BACKARC BASINS ${ }^{1}$
}

\author{
L. M. Parson, ${ }^{2}$ J. W. Hawkins, ${ }^{3}$ and P. M. Hunter ${ }^{2}$
}

\begin{abstract}
A new bathymetric chart has been compiled from conventional wide-beam echo-sounder profiles and recently acquired swath bathymetric data for the Lau Basin between $18^{\circ} 30^{\prime}$ to $21^{\circ} \mathrm{S}$ and $175^{\circ} 30^{\prime}$ and $178^{\circ} \mathrm{W}$. Long-range sidescan sonar data has been interpreted for the same area, and together the two data sets provide powerful imagery revealing the morphological and textural setting for the Ocean Drilling Program Sites 834 through 839. Our interpretation of these data suggests that the Lau Basin may be subdivided into two principal morphotectonic domains on the basis of significantly different topography and structure. The recognition of a fundamental contrast in the crustal character between the earliest formed basin and the most recently formed (1 Ma) seafloor has far-reaching implications for understanding the early geological evolution of all marginal basins, particularly those in backarc settings.
\end{abstract}

Major bathymetric compilations of the Lau Basin have been made by a number of workers, including Hawkins (1974) and Chase (1985); modifications to these base maps have been incorporated into other published reviews of the morphology and geology of the region, the most notable among them being Kroenke (1984). The principal source of data used in the preparation of these charts has been single-track, echo-sounder profiles acquired by survey vessels. The seafloor topography between these lines of primary data has then been interpolated using the subjective skill and judgment of the compiler. Most recently, cruises by French, German, and American survey vessels fitted with multibeam bathymetric swath mapping (SeaBeam) systems have accelerated the capacity to produce more detailed and accurate bathymetric charts, and these latter data are in various stages of publication. The SEAPSO program (Foucher and Shipboard Party, 1986) covered the southern portion of the backarc axis on and near the Valu Fa Ridge, between $20^{\circ}$ and $23^{\circ} \mathrm{S}$. These data were followed by published results from the Sonne 35 and 48 cruises (von Stackleberg, 1990), who in addition surveyed some of the central Lau Basin. Scripps Institution of Oceanography PAPATUA expedition Leg 04 (Hawkins, 1988) and Leg 05 (Craig and Pareda, 1987) surveyed extensively throughout the area, and ROUNDABOUT expeditions Legs 14 and 15 (Hawkins, 1989) provided additional coverage between $15^{\circ}$ and $19^{\circ} \mathrm{S}$. Almost all of these data have been acquired since the last major bathymetric revision, and we present here the first major compilation of bathymetry to include all of these new data.

As well as including all of the data recorded using swath multibeam bathymetric techniques, we have included the most recent soundings acquired by conventional echo-sounding methods. These include data accessed by means of the National Geophysical Data Center (NGDC), Boulder, CO. The chart presented as Figure 1 (back-pocket foldout) forms a small subset of a regional compilation of the bathymetry of the Lau Basin made at a scale 1:375000, which is in the final stages of preparation (Parson et al., unpubl. data). Unlike all previous bathymetric

\footnotetext{
${ }^{1}$ Parson, L., Hawkins, J., Allan, J., et al., 1992. Proc. ODP, Init. Rpts., 135: Ocean Drilling Program (College Station, TX),

${ }^{2}$ Institute of Oceanographic Sciences, Deacon Laboratory, Brook Road, Wormley, Godalming, Surrey GU8 SUB, United Kingdom.

3 Scripps Institution of Oceanography, Geological Division, University of California at San Diego, La Jolla, CA 92093-0215, U.S.A.
}

compilations for this area, one of the ways in which we have been able to increase the objectivity of interpolation between depth measurements is to use acoustic images provided by the GLORIA long-range sidescan sonar system (Somers et al., 1978; Fig. 2, back-pocket foldout). Sidescan sonar records provide a series of acoustical images of the seafloor, the back-scatter intensity of which varies according to the reflectivity of the seafloor. This level of seafloor reflectivity depends on a number of factors, including (1) variations in the incidence (or grazing angle) of the sonar beam, (2) the physical properties of the seafloor, and (3) the roughness of the surface. The sonographs can be interpreted to provide additional qualitative information indicating trend and form of topography, the location and to some extent the scale of major topographic variations (e.g., fault scarps, seamounts). Some restrictions on the full integration of data sets may occur. Severe topographic variations may cause some acoustic shadowing, and a narrow null zone (around $2-3 \mathrm{~km}$ in width) of poor or negligible insonification exists beneath the GLORIA vehicle. We have combined these two principal data sets for the Lau Basin between latitudes $18^{\circ} 30^{\prime}$ and $21^{\circ} \mathrm{S}$ and longitudes $175^{\circ} 30^{\prime}$ and $178^{\circ} \mathrm{W}$. Using these, we have been able to assess the morphotectonic setting for the Ocean Drilling Program (ODP) Leg 135 backarc sites.

As in previous studies of mid-oceanic ridges using GLORIA (e.g., Searle, 1986), broad areas of high back scatter (light tones in the figures) are interpreted as neovolcanic zones with little or no sediment cover (e.g., $<5 \mathrm{~m}$ ). Sediment-free (presumably youthful and actively spreading) ridges are imaged as strongly backscattering bands of variable width, whereas seamounts appear as more localized strongly back-scattering areas that occasionally throw acoustic shadows. Fault scarps appear as sharply defined, highly reflective linear features normally orthogonal to the spreading direction. Areas of relatively thick sediment cover show the least back scatter and appear darkest on the images. These qualitative interpretations of back-scatter strengths are supported by dredge and core samples collected during part of the Charles Darwin Cruise CD33 (Parson et al., 1989).

The GLORIA data are dominated by a number of broad zones of high back scatter, which have previously been identified as lines of recent seafloor generation at spreading ridge axes (Parson et al., 1990). These zones correspond to the segments of the backarc axis termed the Eastern, Intermediate, and Central Lau Spreading Centers. In addition to this semicontinuous line of crustal generation, there is a zone of further high back scattering 
$120 \mathrm{~km}$ to the west of the main GLORIA survey area, informally referred to as the Western Lau Spreading Center (WLSC). It is speculated that this area represents an area of off-axis volcanism, perhaps along strike from an additional zone of off-axis tectonic and volcanic activity recorded around $18^{\circ} 30^{\prime} \mathrm{S}$ and $177^{\circ} 0^{\prime} \mathrm{W}$. Elsewhere on the GLORIA records, there is a varied pattern of backscattering strengths, including areas dominated by extensive north-south linear targets, which we interpret here as fault scarps flanking upstanding basement blocks. A number of subequant, strongly back-scattering targets are interpreted as seamounts.

In constructing our new bathymetric chart, we have attempted to make appropriate allowances for the validity of the data, including possible inaccuracies in the ship positioning for early records collected before the use of transit satellite navigation. The new bathymetry is contoured at 100 -m intervals, and we have used form lines derived from the GLORIA data to constrain our interpolation between bathymetric sounding tracks. We are able to make some first-order assessments of the mesoscale morphology of the basin. We have also used this interpretation to support models of tectonic control to the basin structure and formation.

At the $100-500 \mathrm{~m}$ scale, the topography throughout much of the basin is unlike that of typical spreading fabrics, as recognized using multibeam bathymetric data sets for slowly spreading ridges (see, e.g., Purdy et al., 1990). In the southeastern portion of the study area, the Eastern Lau Spreading Center follows an azimuth of $022^{\circ}$ between $19^{\circ} 20^{\prime} \mathrm{S}, 176^{\circ} \mathrm{W}$ and $21^{\circ} \mathrm{S}, 176^{\circ} 10^{\prime} \mathrm{W}$. The axial bathymetry varies about an average of $2600 \mathrm{~m}$, but outside of the axial zone shoals to the west for an average of between 2500 and $2200 \mathrm{~m}$ water depth. Locally, irregularly shaped platformal areas up to $10 \mathrm{~km}$ across shoal to around $2000 \mathrm{~m}$. Generally, however, a ridge-parallel grain is defined by closely spaced $100-200 \mathrm{~m}$ high ridges. This fabric is identified westward to at least $176^{\circ} 40^{\prime} \mathrm{W}$. Although a faulted scarp fabric is clearly imaged on both GLORIA and SeaBeam data, in detail the structure is clearly characterized by along-strike discontinuities where individual scarps persist for up to a few tens of kilometers, but rarely more. Collectively, the trend is between $020^{\circ}$ and $025^{\circ}$.

To the north of $19^{\circ} 20^{\prime} \mathrm{S}$, the deformation associated with the southerly advance of the Central Lau spreading center propagating rift tip and the concommittant deformation within the Instantaneous Transform Zone (ITZ) has severely disrupted this fabric (Parson et al., 1990). Superimposed on the shear fabrics associated with the ITZ are a series of discrete deep basins, up to $3500-\mathrm{m}$ maximum depth, which appear to form as transient extensional relay rifts between the propagating (CLSC) and annihilated (ELSC) ridge tips.

This regular-spreading fabric associated with the ELSC is observed to extend westward as far as $176^{\circ} 40^{\prime} \mathrm{W}$, beyond which point the regional fabric of closely spaced scarps is absent. Between this longitude and the western margin of the basin floor (at around $178^{\circ} \mathrm{W}$ ), the topography is dominated by a number of steep-sided, elevated linear plateau and ridges up to $30 \mathrm{~km}$ wide and $60 \mathrm{~km}$ long, which separate narrow basins and troughs of similar dimensions.

The structure and morphology of the western half of the Lau Basin thus resemble a broad area of distributed strain, which has resulted in the formation of a horst and graben dominated topography. In contrast, the eastern half of the Lau Basin is characterized by a more typical seafloor fabric carrying a semicontinuous pattern of faults of lower amplitude and higher length-to-throw ratios. Estimates of the amount of extension will be made and will form the basis of a quantified assessment of Lau Basin tectonics (Hawkins, Parson, et al., unpubl. data).

\section{REFERENCES}

Chase, T. E., 1985. Submarine topography of the Tonga-Fiji region and the southern Tonga platform area. In Scholl, D., and Vallier, T. J. (Eds.), Geology and Offshore Resources of Pacific Island ArcsTonga Region. Circum-Pac. Counc. Energy Miner. Resour., Earth Sci. Ser., 2:21-24.

Craig, H., and Pareda, P., 1987. Cruise Report-PAPATUA Expedition, Legs 05 and 06. SIO Ref. Ser., 87-14.

Foucher, J. P., and Shipboard Party, 1986. SEAPSO cruise, Leg IV. Cruise Report, IFREMER.

Hawkins, J. W., 1974. Geology of the Lau Basin: a marginal sea behind the Tonga arc. In Burk, C. A., and Drake, C. L. (Eds.), The Geology of Continental Margins: New York (Springer-Verlag), 505-520. 1988. Cruise Report-PAPATUA Expedition, Leg 04, R/V Thomas Washington. SIO Ref. Ser., No. 88-14. 1989. Cruise Report-ROUNDABOUT Expedition, Legs 14, 15, R/V Thomas Washington. SIO Ref. Ser., No. 89-13.

Kroenke, L., 1984. Cenozoic Development of the Southwest Pacific. CCOP/SOPAC, Tech. Bull., No. 6. U.N. Econ. Soc. Comm. Asia Pac., Suva.

Parson, L. M., Pearce, J. A., Murton, B. J., Hodkinson, R. A., Bloomer, S., Ernewein, M., Huggett, Q. J., Miller, S., Johnson, L., Rodda, P., and Helu, S., 1990. Role of ridge jumps and ridge propagation in the tectonic evolution of the Lau back-arc basin, southwest Pacific. Geology, 18:470-473.

Parson, L. M., et al., 1989. RRS Charles Darwin Cruise 33/8, 5 May-1 June 1988. Geophysical and geological investigation of the Lau backarc basin, SW Pacific. Institute of Oceanographic Sciences, Deacon Laboratory, Cruise Rep., No. 206.

Purdy, G. M., Sempere, J.-C., Schouten, H., DuBois, D., and Goldsmith, R., 1990. Bathymetry of the mid-Atlantic Ridge $24^{\circ}-31^{\circ} \mathrm{N}$. Mar. Geophys. Res., Map Ser., 12:247-252.

Searle, R. C., 1986. GLORIA investigations of oceanic fracture zones: comparative study of the transform fault zone.J. Geol. Soc, , 143:743756.

Somers, M. L., Carson, R. M., Revie, J. A., Edge, R. H., Barrow, B. J., and Andrews, A. G., 1978. GLORIA II-an improved long-range sidescan sonar. In Proceedings of the IEEE-IERE Subconference on Offshore Instrumentation and Communications Post-doc. BPS Publications Limited, London, J16-J24.

von Stackelberg, U., 1990. R.V. Sonne Cruise SO48: summary of results testing a model of mineralisation. Mar. Min., 9:135-144.

\section{Ms 135A-103}

